\title{
Silicon Fertilization Improves the Maize (Zea mays L.) Performance under Limited Moisture Supply
}

\author{
M. Amin 1 , R. Ahmad ${ }^{1 *}$, A. Ali ${ }^{2}$, M. Aslam ${ }^{1}$ and D.J. LeE ${ }^{3}$ \\ ${ }^{1}$ Department of Agronomy, University of Agriculture, Faisalabad \\ ${ }^{2}$ Department of Agronomy, Ghazi University, Dera Ghazi Khan, Pakistan \\ ${ }^{3}$ Department of Crop Science and Biotechnology, Dankook University, South Korea
}

(Received 2 March 2015; Accepted 16 April 2015;

Communicated by J. Kubat)

\begin{abstract}
Field crops are subjected to numerous inconsiderate climatic hazards that negatively affect physiological processes, growth and yield. Drought is one of the major abiotic factors that limits the agricultural productivity especially in the arid and semi-arid areas of the globe. Silicon $(\mathrm{Si})$ is a naturally occurring beneficial nutrient which modulates plant growth and development events and has been known to improve the crop tolerance to abiotic stresses. With the objective to investigate the role of silicon nutrition on maize hybrids under limited moisture supply, a two year field study was conducted during 2010-11 at Post Graduate Research Station (PARS), University of Agriculture Faisalabad, Pakistan. We evaluated growth of two maize hybrids $\mathrm{P}-33 \mathrm{H} 25$ and $\mathrm{FH}-810$ under well watered (100\% field capacity) and water deficit situation (60\% field capacity) as affected by Si application. Silicon was added in soil @100 mg/kg using Calcium Silicate as source. Water deficit condition significantly reduced agro-morphological and physiological attributes of maize plants. Silicon application significantly increased the plant height, leaf area index, yield and related attributes along with improvement in photosynthetic rate, leaf water status and osmotic adjustment under limited moisture supply. It was concluded that silicon application to droughtstressed maize enhanced its growth and yield owing to improved photosynthetic rate, higher osmotic adjustment, increased water status and lowered transpiration.
\end{abstract}

Keywords: water deficit, silicon, hybrid maize, gaseous exchange, water relations, yield

\section{Introduction}

Food security is a big challenge to feed the burgeoning population of the globe. Currently, 1.02 billion people of the world suffer from hunger (FAO 2011). Meanwhile, over the next 30 to 50 years with an estimated population of 9-10 billion people, the biggest problem that arises is the food security for growing population, especially in the least developed countries (Beddington 2010). The dilemma is increased when field crops are subjected to numerous inconsiderate climatic hazards like flood, drought, extreme temperature, salinity, pollutants and heat that negatively affect physiological processes, growth and yield of crops (Boubacar 2012). Among these drought stress is one of the most dev-

\footnotetext{
*Corresponding author; E-mail: uafanser@gmail.com; Phone: 00923017175236
} 
astating stressful environments for plant growth and production (Farooq et al. 2008; Peleg et al. 2011). One viable strategy of overcoming the drought-induced injurious effect on plant growth is the exogenous application of inorganic nutrients (Ashraf and Foolad 2007). By adopting this strategy, Tuna et al. (2008) have recommended the supplements of Si to plants subjected to the salt affected soils, addition of Si has been considered beneficial for improving crop tolerance to both biotic and abiotic stresses (Ahmed et al. 2011; Kojic et al. 2012). The ameliorative role of Si to adverse effects of drought has been examined in different crops e.g. sugarcane (Bokhtiar et al. 2012), rice (Chen et al. 2011), wheat (Karrou et al. 2012), tomato (Aranda et al. 2006), cowpea (Mali and Aery 2008), sorghum (Ahmed et al. 2011) and soybean (Hamayun et al. 2010). Plants deprived of Si often show poor development and reproduction, but it depends on the type of plant species. In general, plants belonging to family Gramineae accumulate much more silicon than that by other species belonging to other families. It has also been reported that most dicot plants absorb Si passively but monocots can efficiently exclude $\mathrm{Si}$ from their roots (Kurdali and Al-Shammaa 2010; Chen et al. 2011).

Different mechanisms are reported to induce drought tolerance in plants through silicon treatment including increased water status of plants (Kurdali et al. 2013), improved photosynthetic efficiency (Chen et al. 2011), osmoregulation or osmotic adjustment (Sacala 2009; Ahmad and Haddad 2011), maintenance of photosynthetic apparatus and pigments (Hamayun et al. 2010; Chutipaijit et al. 2012), up-regulation of plant defense system (Ahmed et al. 2013), and lowered transpiration rate (Kurdali et al. 2013).

Therefore, Si application to crops can be an efficient and viable management practice to improve production potential and to enable plants to withstand water deficit conditions. We hypothesize that exogenous application of Si under water deficit condition may substantially improve the maize water status, photosynthetic rate and yield. Keeping in view the above facts, an experiment was conducted to explore the role of Si application in order to alleviate the drought stress in maize hybrids.

\section{Materials and Methods}

The research was conducted at Postgraduate Agricultural Research Station, University of Agriculture Faisalabad, Pakistan. The station is located between longitude $73^{\circ} 74$ East, latitude $30^{\circ} 31.5$ North, with an elevation of 184 meters above sea level. This area is located in the Indus plain among the Indus river tributaries. The soil was taken from the field and soil samples were sent to soil testing laboratory for analysis. The experimental soil texture was sandy loam with $\mathrm{pH} 8.1$, total exchangeable salts $0.29 \mathrm{dS} \mathrm{m}^{-1}, 0.81 \%$ of organic matter, total nitrogen $0.049 \%$, available phosphorus $8 \mathrm{ppm}$, exchangeable potassium $110 \mathrm{ppm}$ and extractable silicon $30 \mathrm{ppm}$. The design of experiment was randomized complete block (RCBD) with split-split arrangement randomizing the maize hybrids (P-33H25 and FH-810) in main plots, irrigation levels (100\% and $60 \%$ field capacity) in sub plots and silicon application (0 and $100 \mathrm{mg} / \mathrm{kg}$ of soil) in sub-sub plot with three replications. The field was well prepared by ploughing and followed by planking. The ridges were made with the help of tractor mounted ridger at $75 \mathrm{~cm}$ apart from each other. 
The crop was sown on August 5 and August 7 during the years 2010 and 2011, respectively. A fertilizer dose of $250 \mathrm{~kg} \mathrm{~N}+125 \mathrm{~kg} \mathrm{P}_{2} \mathrm{O}_{5}$ and $125 \mathrm{~kg} \mathrm{~K}_{2} \mathrm{O} \mathrm{ha}{ }^{-1}$ was applied. All the $\mathrm{P}, \mathrm{K}$ and $1 / 3$ of $\mathrm{N}$ fertilizer were applied before sowing while remaining $\mathrm{N}$ was applied in two splits. The drought was imposed one month after germination by maintaining $60 \%$ FC after. A flume was installed at the start of field water channel to measure the quantity of water. The measured quantity of water was applied to control plot ( $100 \%$ field capacity) and drought stressed plots (60\% field capacity) to maintain the required field capacity level with the help of cut throat flume. The crop was kept free of weeds and pests by following suitable plant protection measures. The crop was harvested at its physiological maturity. There was soil application of silicon $(100 \mathrm{mg} / \mathrm{kg})$ in the form of calcium silicate after dissolving it in $\mathrm{KOH}$ at $71{ }^{\circ} \mathrm{C}$ (Ali et al. 2009). Harvesting was done at physiological maturity of crop. The daily average weather data on month basis for study period is given in Table 1.

Table 1. Month wise daily average weather data for the study period

\begin{tabular}{|l|c|c|c|c|c|c|c|c|}
\hline \multirow{2}{*}{ Months } & \multicolumn{2}{|c|}{ Rainfall $(\mathrm{mm})$} & \multicolumn{2}{c|}{ Temperature $\left({ }^{\circ} \mathrm{C}\right)$} & \multicolumn{2}{c|}{ R. Humidity $(\%)$} & \multicolumn{2}{c|}{ Potential ET (mm) } \\
\cline { 2 - 9 } & 2010 & 2011 & 2010 & 2011 & 2010 & 2011 & 2010 & 2011 \\
\hline August & 7.31 & 2.99 & 30.5 & 29.8 & 74.6 & 74.7 & 3.4 & 3.1 \\
\hline September & 2.88 & 5.17 & 28.6 & 28.3 & 66.8 & 75.8 & 3.4 & 2.8 \\
\hline October & 0 & 0.01 & 26.3 & 24.7 & 59.6 & 61.0 & 3.0 & 3.3 \\
\hline November & 0 & 0 & 18.8 & 20.5 & 62.3 & 61.2 & 2.1 & 1.8 \\
\hline
\end{tabular}

\section{Determination of irrigation levels at field}

Gravimetric procedure of direct soil water measurement was applied to determine the water content in the soil. Soil sampling for soil moisture measurement was carried out regularly on alternate days keeping in view the weather conditions. Composite soil samples at the depth intervals of $30 \mathrm{~cm}$ up to $100 \mathrm{~cm}$ were taken on taking into consideration of maize growth stage from randomly located sites in each plot for moisture determination, as the maximum moisture extraction depth of root zone of maize crop was taken as $100 \mathrm{~cm}$ (Nachabe 1998).

\section{Depth of irrigation water}

Irrigation was applied to the respective plots as soon as the desired available soil moisture depletion level reached in the soil of crop root zone. Depth of irrigation for each field capacity level was predetermined by adopting the direct measurement or field sampling method of crop water requirement as reported by Majumdar (2002) and Tariq and Usman (2009):

$$
d=\frac{\left(F_{c}-M_{b}\right)(B d) D}{100}
$$


Here

$d=$ Depth of water to be applied in $(\mathrm{cm})$

$D=$ Depth of root zone $(\mathrm{cm})$

$F_{c}=$ Moisture content at field capacity as per treatment ( $100 \%$ or $60 \%$ field capacity) in percent by weight

$B d=$ Bulk density of soil $\mathrm{g} / \mathrm{cm}^{3}$

$M_{b}=$ water content in soil before irrigation in percent by weight

Discharge of water applied to each treatment was determined with the help of a cut throat flume ( $\left.3^{\prime} \times 8^{\prime \prime}\right)$. The time required to supply the required depth of irrigation water to each plot was calculated according to following equation (Rafiq 2001):

Where

$$
t=\frac{d \times a}{q}
$$

$$
\begin{array}{ll}
t & =\text { time in hours } \\
d & =\text { depth of water in inches } \\
a & =\text { area in acres } \\
q & =\text { discharge of irrigation water in } \mathrm{ft}^{3} / \mathrm{s} .
\end{array}
$$

\section{Agronomic attributes}

Following agronomic attributes were recorded in this study like plant height, leaf area index, and cob length, number of grains per cob, 100-grain weight, grain yield and biological yield per plant.

\section{Water relation parameters}

\section{Relative water content (\%)}

To determine relative water content the third uppermost fully expanded youngest leaf from two plants of each treatment was taken. The leaves were quickly transferred to laboratory by sealing in plastic bags after cutting from the base of lamina. Leaf fresh weight (LFW) was obtained within one and half hour after removal of leaves from plants. After that leaves were soaked for $16-18$ hours at room temperature $25 \pm 2{ }^{\circ} \mathrm{C}$ and then leaves blotted dry carefully with the help of tissue paper to determine the leaf turgid weight (LTW). The leaf dry weight (LDW) was found after drying the samples of leaves in an oven at $70^{\circ} \mathrm{C}$ for 72 hours. Relative leaf water content (RLWC) was calculated from the formula proposed by Turner (1986) and then averaged.

$$
\text { RLWC }(\%)=(L F W-L D W) /(L T W-L D W) \times 100
$$


Where

RLWC = relative leaf water content,

LFW = fresh weight of leaf,

LDW = dry weight of leaf,

LTW = turgid weight of leaf.

\section{Leaf water potential (MPa)}

From top of plants the third youngest fully expanded leaf from each treatment was excised in the morning time (6:00 a.m.-8:00 a.m.) to avoid evapotranspiration. Water potential apparatus, using the method proposed by Scholander et al. (1964) was used for determination of leaf water potential. The leaf (third fully expanded youngest leaf) was sealed in the pressure chamber in such a way that the cut surface protruding out of the hole then pressure was applied from a cylinder of compressed gas to the leaf until sap from xylem appeared at the surface of cut.

\section{Leaf osmotic Potential (MPa)}

To determine leaf osmotic potential same leaf sample as for determination of water potential was used. Sample was frozen for more than 7 days in a freezer at below $-20{ }^{\circ} \mathrm{C}$, after that leaf was thawed and then leaf sap was extracted by pressing leaf sample with the use of glass rod. The osmotic potential was determined by vapor pressure osmometer using the leaf sap directly (Nobel 1983).

\section{Gas exchange observation}

The various leaf gas exchange parameters (Photosynthetic rate $\left(\mu \mathrm{mol} / \mathrm{m}^{2} / \mathrm{s}\right)$ and Transpiration rate $\left(\mathrm{mmol} / \mathrm{m}^{2} / \mathrm{s}\right)$ were estimated with the help of an open system LCA-4 ADC portable infrared gas analyzer (Analytical Development Company, Hoddeson, England). Observations were made on $3^{\text {rd }}$ leaf from the top of plant that was fully expanded and youngest in the morning time from 8:00 a.m. to 10:00 a.m. The following adjustments were carried out to take observations: leaf chamber temperature varied from $25-28{ }^{\circ} \mathrm{C}$, surface area of leaf $6.25 \mathrm{~cm}^{2}$, ambient $\mathrm{CO}_{2}$ concentration was $371 \mu \mathrm{mol} \mathrm{mol}{ }^{-1}$, ambient pressure in chamber was $97.95 \mathrm{kPa}$, Photosynthetically active radiations (PAR) at the surface of leaf were maximum up to $770 \mu \mathrm{mol} / \mathrm{m}^{2} / \mathrm{s}$, leaf chamber volume gas flow rate was $296 \mathrm{~mL} \mathrm{~min}{ }^{-1}$ and molar gas flow rate into chamber was $400 \mu \mathrm{mol} / \mathrm{s}$.

\section{Statistical analysis}

Data collected were analyzed statistically using Fisher' analysis of variance technique. Difference among the treatments means was compared using least significant difference test at 5\% probability level (Steel et al. 1997) using the MSTAT C computer software. 


\section{Results}

\section{Crop growth and yield attributes}

Water deficit significantly reduced the plant height in both maize hybrids during either of the study years (autumn 2010 or 2011). There was a reduction of 27.83 and $41.40 \%$ in maize cultivars $\mathrm{P}-33 \mathrm{H} 25$ and $\mathrm{FH}-810$, respectively in first year while a decrease of 23.96 and $35.50 \%$ was observed in maize genotypes $\mathrm{P}-33 \mathrm{H} 25$ and $\mathrm{FH}-810$, respectively during autumn 2011. However, silicon fertilization promoted the plant height under well watered and deficit condition. The results from the Table 2 showed that under water deficit longer plants were observed where silicon was applied in both maize hybrids while minimum plant height 99.94 and $118.81 \mathrm{~cm}$ during 2010 and 2011, respectively was observed in maize hybrid FH-810 without silicon application under water deficit situation (Table 2).

The perusal of the Table 3 showed that drought stress significantly reduced the leaf area index in both maize hybrids. Maximum reduction of 35.71 and $40.49 \%$ was observed in maize hybrid FH-810 during 2010 and 2011, respectively. However, hybrid P-33H25 showed a decrease of 27.01 and 26.55\% in leaf area index during 2010 and 2011, respectively. Silicon nutrition under drought condition was found to have significant positive effect on this attribute in maize hybrids during both years of study. However, maximum leaf area index was recorded in maize hybrid $\mathrm{P}-33 \mathrm{H} 25$ where silicon was used under well watered condition (100\% FC) during both years of study (Table 3$)$.

Table 2. Influence of silicon on plant height $(\mathrm{cm})$ of maize hybrids grown under water deficit

\begin{tabular}{|c|c|c|c|c|c|}
\hline \multirow{2}{*}{ Hybrids } & \multirow{2}{*}{ Moisture levels } & \multicolumn{2}{|c|}{2010} & \multicolumn{2}{|c|}{2011} \\
\cline { 3 - 6 } & & Si $0 \mathrm{mg} / \mathrm{kg}$ & Si $100 \mathrm{mg} / \mathrm{kg}$ & Si $0 \mathrm{mg} / \mathrm{kg}$ & Si $10 \mathrm{mg} / \mathrm{kg}$ \\
\hline \multirow{2}{*}{ P-33H25 } & WW & $178.50 \mathrm{~b}$ & $194.68 \mathrm{a}$ & $182.14 \mathrm{c}$ & $206.92 \mathrm{a}$ \\
\cline { 2 - 6 } & WD & $128.83 \mathrm{~d}$ & $141.79 \mathrm{c}$ & $138.50 \mathrm{e}$ & $164.70 \mathrm{~d}$ \\
\hline \multirow{2}{*}{ FH-810 } & WW & $170.56 \mathrm{~b}$ & $177.32 \mathrm{~b}$ & $184.19 \mathrm{c}$ & $196.45 \mathrm{~b}$ \\
\cline { 2 - 6 } & WD & $99.94 \mathrm{e}$ & $123.59 \mathrm{~d}$ & $118.81 \mathrm{f}$ & $157.29 \mathrm{~d}$ \\
\hline
\end{tabular}

$\operatorname{LSD}(\mathrm{H} \times \mathrm{D} \times \mathrm{Si})=10.20 ; \mathrm{LSD}(\mathrm{H} \times \mathrm{D} \times \mathrm{Si})=8.74$.

Table 3. Influence of silicon on leaf area index of maize hybrids grown under water deficit in autumn season

\begin{tabular}{|c|c|c|c|c|c|}
\hline \multirow{2}{*}{ Hybrids } & \multirow{2}{*}{ Moisture levels } & \multicolumn{2}{|c|}{2010} & \multicolumn{2}{|c|}{2011} \\
\cline { 3 - 6 } & & Si $0 \mathrm{mg} / \mathrm{kg}$ & Si $100 \mathrm{mg} / \mathrm{kg}$ & $\mathrm{Si} 0 \mathrm{mg} / \mathrm{kg}$ & Si $10 \mathrm{mg} / \mathrm{kg}$ \\
\hline \multirow{3}{*}{ P-33H25 } & WW & $3.85 \mathrm{~b}$ & $4.40 \mathrm{a}$ & $4.67 \mathrm{~b}$ & $5.10 \mathrm{a}$ \\
\cline { 2 - 6 } & WD & $2.81 \mathrm{f}$ & $3.36 \mathrm{~d}$ & $3.43 \mathrm{c}$ & $3.68 \mathrm{c}$ \\
\hline \multirow{2}{*}{ FH-810 } & WW & $3.78 \mathrm{c}$ & $4.03 \mathrm{bc}$ & $4.52 \mathrm{~b}$ & $4.70 \mathrm{~b}$ \\
\cline { 2 - 6 } & WD & $2.43 \mathrm{~g}$ & $3.10 \mathrm{e}$ & $2.69 \mathrm{~d}$ & $3.44 \mathrm{c}$ \\
\hline
\end{tabular}

$\operatorname{LSD}(\mathrm{H} \times \mathrm{D} \times \mathrm{Si})=0.18 ; \operatorname{LSD}(\mathrm{H} \times \mathrm{D} \times \mathrm{Si})=0.34$. 
Yield and related attributes of maize hybrids were also drastically affected by water deficit stress while higher cob length, cob girth, number of grains per cob, biological and grain yield was recorded for plants that were fertilized with silicon under both well watered and water deficit condition (Tables 4-8). However, more silicon based improvement in above mentioned parameters was noticed where silicon was added to plants of maize that were grown under limited moisture ( $60 \%$ FC) supply during both of the study years. Nonetheless, more number of grains per cob, biological and grain yield was recorded during the second year of study i.e. 2011 (Tables 6-8). There was a greater reduction in grain yield in hybrid FH-810 under drought condition $(60 \%$ FC) than $\mathrm{P}-33 \mathrm{H} 25$

Table 4. Influence of silicon on cob length $(\mathrm{cm})$ of maize hybrids grown under water deficit in autumn season

\begin{tabular}{|c|c|c|c|c|c|}
\hline \multirow{2}{*}{ Hybrids } & \multirow{2}{*}{ Moisture levels } & \multicolumn{2}{|c|}{2010} & \multicolumn{2}{|c|}{2011} \\
\cline { 3 - 6 } & & Si $0 \mathrm{mg} / \mathrm{kg}$ & Si $100 \mathrm{mg} / \mathrm{kg}$ & Si $0 \mathrm{mg} / \mathrm{kg}$ & Si $100 \mathrm{mg} / \mathrm{kg}$ \\
\hline \multirow{2}{*}{ P-33H25 } & WW & $15.58^{\mathrm{NS}}$ & 16.59 & $16.84 \mathrm{bc}$ & $18.60 \mathrm{a}$ \\
\cline { 2 - 6 } & WD & 11.18 & 12.55 & $13.02 \mathrm{f}$ & $15.10 \mathrm{~d}$ \\
\hline \multirow{2}{*}{ FH-810 } & WW & 15.51 & 16.15 & $16.40 \mathrm{c}$ & $17.33 \mathrm{~b}$ \\
\cline { 2 - 6 } & WD & 11.17 & 11.33 & $11.20 \mathrm{~g}$ & $13.87 \mathrm{e}$ \\
\hline
\end{tabular}

$\operatorname{LSD}(\mathrm{H} \times \mathrm{D} \times \mathrm{Si})=0.59$.

Table 5. Influence of silicon on cob diameter $(\mathrm{cm})$ of maize hybrids grown under water deficit in autumn season

\begin{tabular}{|c|c|c|c|c|c|}
\hline \multirow{2}{*}{ Hybrids } & \multirow{2}{*}{ Moisture levels } & \multicolumn{2}{|c|}{2010} & \multicolumn{2}{|c|}{2011} \\
\cline { 3 - 6 } & & Si $0 \mathrm{mg} / \mathrm{kg}$ & Si $100 \mathrm{mg} / \mathrm{kg}$ & Si $0 \mathrm{mg} / \mathrm{kg}$ & Si $100 \mathrm{mg} / \mathrm{kg}$ \\
\hline \multirow{2}{*}{ P-33H25 } & WW & $4.47 \mathrm{~b}$ & $5.75 \mathrm{a}$ & $4.11^{\mathrm{NS}}$ & 4.55 \\
\cline { 2 - 6 } & WD & $2.74 \mathrm{e}$ & $3.39 \mathrm{~d}$ & 3.10 & 3.55 \\
\hline \multirow{2}{*}{ FH-810 } & WW & $3.99 \mathrm{c}$ & $4.49 \mathrm{~b}$ & 4.09 & 4.38 \\
\cline { 2 - 6 } & WD & $2.56 \mathrm{e}$ & $3.52 \mathrm{~cd}$ & 3.07 & 3.33 \\
\hline
\end{tabular}

$\operatorname{LSD}(\mathrm{H} \times \mathrm{D} \times \mathrm{Si})=0.47$.

Table 6. Influence of silicon on number of grains per cob of maize hybrids grown under water deficit in autumn season

\begin{tabular}{|c|c|c|c|c|c|}
\hline \multirow{2}{*}{ Hybrids } & \multirow{2}{*}{ Moisture levels } & \multicolumn{2}{|c|}{2010} & \multicolumn{2}{|c|}{2011} \\
\cline { 3 - 6 } & & Si $0 \mathrm{mg} / \mathrm{kg}$ & Si $100 \mathrm{mg} / \mathrm{kg}$ & Si $0 \mathrm{mg} / \mathrm{kg}$ & Si $100 \mathrm{mg} / \mathrm{kg}$ \\
\hline \multirow{2}{*}{ P-33H25 } & WW & $323.99 \mathrm{~b}$ & $355.04 \mathrm{a}$ & $336.22 \mathrm{~b}$ & $389.19 \mathrm{a}$ \\
\cline { 2 - 6 } & WD & $228.67 \mathrm{~d}$ & $253.55 \mathrm{c}$ & $262.48 \mathrm{de}$ & $285.78 \mathrm{c}$ \\
\hline \multirow{2}{*}{ FH-810 } & WW & $308.76 \mathrm{~b}$ & $326.34 \mathrm{~b}$ & $315.21 \mathrm{~b}$ & $336.72 \mathrm{~b}$ \\
\cline { 2 - 6 } & WD & $173.20 \mathrm{e}$ & $234.87 \mathrm{~cd}$ & $240.40 \mathrm{e}$ & $284.81 \mathrm{~cd}$ \\
\hline
\end{tabular}

$\operatorname{LSD}(\mathrm{H} \times \mathrm{D} \times \mathrm{Si})=23.44 ; \mathrm{LSD}(\mathrm{H} \times \mathrm{D} \times \mathrm{Si})=22.48$. 
Table 7. Influence of silicon on biological yield per ha-1 ( $\mathrm{t}$ ) of maize hybrids grown under water deficit in autumn season

\begin{tabular}{|c|c|c|c|c|c|}
\hline \multirow{2}{*}{ Hybrids } & \multirow{2}{*}{ Moisture levels } & \multicolumn{2}{|c|}{2010} & \multicolumn{2}{|c|}{2011} \\
\cline { 3 - 6 } & & Si $0 \mathrm{mg} / \mathrm{kg}$ & Si $100 \mathrm{mg} / \mathrm{kg}$ & Si $0 \mathrm{mg} / \mathrm{kg}$ & Si $100 \mathrm{mg} / \mathrm{kg}$ \\
\hline \multirow{2}{*}{ P-33H25 } & WW & $12.01 \mathrm{c}$ & $13.19 \mathrm{a}$ & $14.19 \mathrm{~b}$ & $15.32 \mathrm{a}$ \\
\cline { 2 - 6 } & WD & $9.91 \mathrm{e}$ & $10.91 \mathrm{~d}$ & $11.42 \mathrm{c}$ & $12.16 \mathrm{c}$ \\
\hline \multirow{2}{*}{ FH-810 } & WW & $12.11 \mathrm{bc}$ & $12.68 \mathrm{ab}$ & $13.97 \mathrm{~b}$ & $14.43 \mathrm{~b}$ \\
\cline { 2 - 6 } & WD & $8.74 \mathrm{f}$ & $10.48 \mathrm{de}$ & $9.84 \mathrm{~d}$ & $11.92 \mathrm{c}$ \\
\hline
\end{tabular}

$\operatorname{LSD}(\mathrm{H} \times \mathrm{D} \times \mathrm{Si})=0.60 ; \operatorname{LSD}(\mathrm{H} \times \mathrm{D} \times \mathrm{Si})=0.76$.

Table 8. Influence of silicon on grain yield per ha-1 ( $\mathrm{t}$ ) of maize hybrids grown under water deficit in autumn season

\begin{tabular}{|c|c|c|c|c|c|}
\hline \multirow{2}{*}{ Hybrids } & \multirow{2}{*}{ Moisture levels } & \multicolumn{2}{|c|}{2010} & \multicolumn{2}{|c|}{2011} \\
\cline { 3 - 6 } & & Si $0 \mathrm{mg} / \mathrm{kg}$ & Si $100 \mathrm{mg} / \mathrm{kg}$ & Si $0 \mathrm{mg} / \mathrm{kg}$ & Si $100 \mathrm{mg} / \mathrm{kg}$ \\
\hline \multirow{2}{*}{ P-33H25 } & WW & $4.55 \mathrm{c}$ & $5.42 \mathrm{a}$ & $5.61 \mathrm{bc}$ & $6.40 \mathrm{a}$ \\
\cline { 2 - 6 } & WD & $3.23 \mathrm{f}$ & $3.98 \mathrm{~d}$ & $4.09 \mathrm{f}$ & $4.90 \mathrm{~d}$ \\
\hline \multirow{2}{*}{ FH-810 } & WW & $4.53 \mathrm{c}$ & $4.92 \mathrm{~b}$ & $5.50 \mathrm{c}$ & $5.87 \mathrm{~b}$ \\
\cline { 2 - 6 } & WD & $2.69 \mathrm{~g}$ & $3.63 \mathrm{e}$ & $3.54 \mathrm{~g}$ & $4.51 \mathrm{e}$ \\
\hline
\end{tabular}

$\operatorname{LSD}(\mathrm{H} \times \mathrm{D} \times \mathrm{Si})=0.18 ; \operatorname{LSD}(\mathrm{H} \times \mathrm{D} \times \mathrm{Si})=0.26$.

Means not sharing the same letter differ significantly from one another at $5 \%$ probability level; $\mathrm{Si}=$ silicon, $\mathrm{WW}=$ wellwatered, WD = water-deficit.

during both years of study (autumn 2010 and 2011). However, silicon application proved to be beneficial for both maize hybrids (P-33H25 and FH-810) under either of the moisture regime (100\% FC or $60 \%$ FC) during both years of study. Maximum grain yield was recorded in hybrid $\mathrm{P}-33 \mathrm{H} 25$ with silicon addition under well watered condition while lower was exhibited by hybrid FH-810 under water deficit ( $60 \%$ FC) without silicon nutrition during first year of study and similar trend was observed in second year of experimentation (Tables 4-8).

\section{Gas exchange parameters}

Silicon nutrition proved to be advantageous for improving photosynthetic rate under water deficit $(60 \%$ FC) for maize cultivars P-33H25 and FH-810. Silicon fertilized plants of hybrid P-33H25 also responded well under well watered condition (100\% FC) during both years (autumn 2010 or 2011). Hybrid FH-810 also showed significant increase in photosynthetic rate during the course of study. Silicon fed plants of both hybrids under water deficit condition $(60 \% \mathrm{FC})$ showed more photosynthetic rate as compared to plants that were grown without silicon application during both years of study. Water deficit condition significantly reduced the transpiration rate in both maize hybrids during 2010 and 2011. Higher transpiration rate was recorded where silicon was not added to plants of 
both maize hybrids under well watered condition or drought condition. However, more transpiration rate was observed in plants that were grown with optimal moisture without silicon application (Fig. 2).

\section{Water relation parameters}

The results given in Fig. 1 illustrated that relative water content decreased when maize cultivars $\mathrm{P}-33 \mathrm{H} 25$ and $\mathrm{FH}-810$ were exposed to water deficit condition. However, silicon fed plants of both maize hybrids showed greater relative water content under well watered or drought stressed condition. However, well watered silicon fed plants of maize hybrid $\mathrm{P}-33 \mathrm{H} 25$, possessed more relative water content over FH-810 under similar environment during both years (autumn 2010 and 2011). However, maximum relative water content
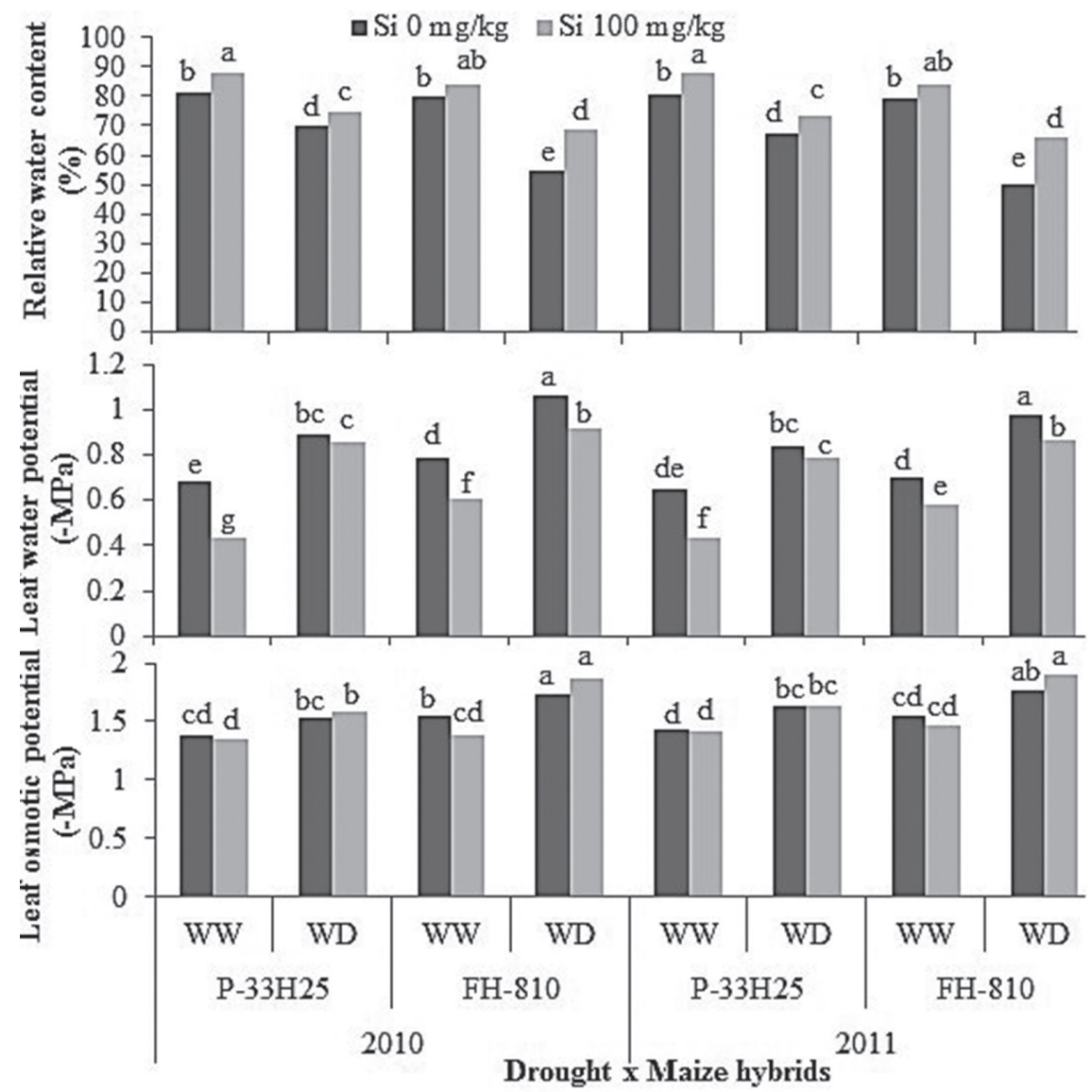

Figure 1. Effect of silicon on the water relation of maize hybrids grown under water deficit conditions. $\mathrm{Si}=$ silicon; $\mathrm{WW}=$ well watered; $\mathrm{WD}=$ water deficit 
was maintained by silicon fertilized plants of hybrid P-33H25 under well watered condition $(100 \%$ FC). Nonetheless, the minimum relative water content was exhibited by drought stressed plants (without silicon) of maize cultivar FH-810 during both years of experimentation (autumn 2010 or 2011), throughout the growing period. Water deficit condition (60\% field capacity) caused a significant reduction (more negative) in leaf water potential of both maize hybrids (Fig. 1). There was more reduction in leaf water potential of hybrid FH-810 over P-33H25 under drought condition (60\% FC) during both years (autumn 2010 and 2011). Silicon fed plants of both maize hybrids had more (less negative) leaf water potential under either of the moisture regime $(100 \%$ or $60 \%$ FC) during both years. However, more leaf water potential was recorded in silicon-mediated plants of hybrid $\mathrm{P}-33 \mathrm{H} 25$ under well watered situation (100\% FC) during both years. The minimum leaf water potential was recorded in drought stressed plants of maize genotype FH-810 where silicon was not applied during both years. Drought had an influence on the osmotic potential (more negative) in both maize cultivars under study during the course of study i.e. autumn 2010 and 2011 (Fig. 1). Silicon fed water-stressed plants of maize cultivars lowered their osmotic potential while silicon-treated well watered plants improved their osmotic potential.

\section{Discussion}

The present research study was aimed to improve the performance of hybrid maize by silicon fertilization under limited moisture supply in field condition. Normally, the deleterious effect of drought is eliminated through silicon nutrition by inducing several physiological changes e.g. osmotic adjustment (Ahmad and Haddad 2011), improved photosynthetic rate (Ahmed et al. 2011; Kurdali et al. 2013), maintenance of photosynthetic pigments and apparatus (Chutipaijit et al., 2012), increased water status of plants (Ahmed et al. 2013), decrease decomposition of chlorophyll (Kurdali et al. 2013), lowered transpiration rate (Ahmed et al. 2013), improved nutrient use efficiency (Miao et al. 2010) and up-regulation of plant defense system (Sacala 2009; Milne et al., 2012) and finally increased yield (Hakim et al. 2012) in plants facing water deficit. A significant improvement in shoot length, and leaf area index with silicon fertilization reveals that it was beneficial to enhance the growth of maize hybrids under drought stress (Tables 3 and 4). Likewise, Hamayun et al. (2010) reported that adverse effects of $\mathrm{NaCl}$ and PEG on plant growth were alleviated by adding $100 \mathrm{mg} / \mathrm{kg}$ and $200 \mathrm{mg} / \mathrm{kg}$ Si to salt and drought stressed plants of soybean. They observed $14.18 \%, 15.25 \%$ and $13.09 \%$ increase in shoot length, shoot dry weight and chlorophyll content, respectively of silicon fed drought-stressed plants of soybean than drought-stressed plants that were grown without silicon addition. Siliconmediated increase in growth of water deficit stressed plants may be due to the important role of silicon in the promotion of water status of stressed plants (Ahmed et al. 2013) that might be the reason of lowered transpiration (Gao et al. 2006). Nonetheless, increase in the photosynthetic rate in silicon-fertilized drought-stressed plants may improve the growth (Ahmed et al. 2013). 
Water deficit significantly affected the leaf water potential and osmotic potential in maize genotypes during the study period (Fig. 1). Nonetheless, silicon nutrition maintained higher water potential, lowered osmotic potential and improved relative water content that showed improved drought tolerance in Si-treated maize compared to plants that were grown without silicon under limited moisture supply. Improved performance of drought-stressed plants may be contributed to Si nutrition that causes osmotic adjustment through maintaining the turgor pressure at low water potential (Sonobe et al. 2011; Ahmed et al. 2013). Exogenous silicon application considerably improved the relative water content (Fig. 1) under both well watered and water deficit condition. Silicon fertilized drought stressed plants of soybean maintained $29.53 \%$ higher relative water content than deprived drought stressed seedlings (Shen et al. 2010). The enhanced ability of drought stressed silicon treated plants might be related to decrease in transpiration rate because of silicon deposition beneath the cutical (Sacala 2009; Kurdali et al. 2013).

It is generally known that the reduced rate of photosynthesis resulted in reduced plant growth in most plants. In this study, the imposition of drought significantly reduced the efficiency of photosynthesis with a concomitant decrease in transpiration. However, exogenously applied Si significantly enhanced photosynthetic rate while lowered the transpiration rate during both years (Fig. 2). Shen et al. (2010) investigated that Si addition under well-watered condition resulted in an increase of $5.97 \%$ photosynthetic rate while Si mediated drought stressed ( $-0.5 \mathrm{MPa}$, simulated with $20 \%$ polyethylene glycol) plants maintained $20.99 \%$ higher photosynthetic rate than Si deprived water stressed plants. The

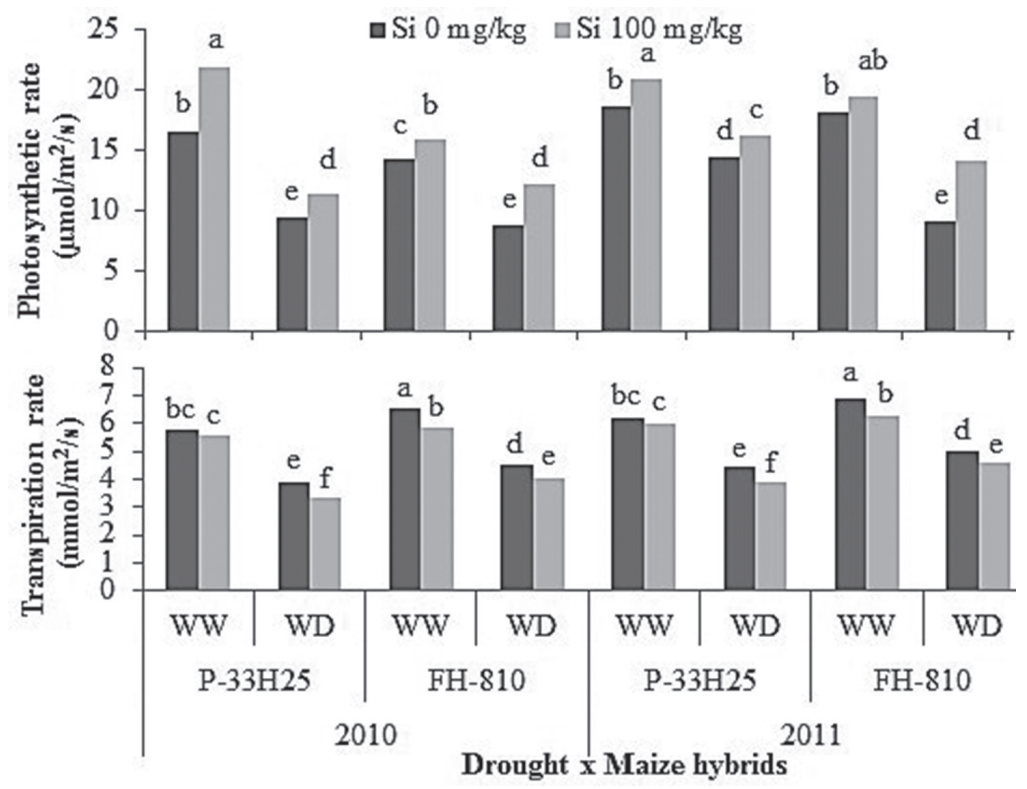

Figure 2. Effect of silicon on the photosynthetic rate and transpiration rate of maize hybrids grown under water deficit conditions. $\mathrm{Si}=$ silicon; $\mathrm{WW}=$ well watered; $\mathrm{WD}=$ water deficit 
improvement in photosynthesis might be related to ameliorative effect of silicon on plants under water stress that deposited as colloidal silica gel $\left(\mathrm{SiO}_{2}\right)$ in the xylem vessels and cell walls of leaves. So, decreases the bypass flow of transpired water that crosses the root cells towards the xylem vessels and provides a barrier to cuticular transpiration (Savvas et al. 2009). Such effects of Si increase the relative water content of plant tissues so hold leaves erect and strengthening the stem to prevent lodging that results in improved accommodation of light in plant community thus improving photosynthesis (Abdalla 2009). The silicon based increase in the photosynthesis of drought stressed plants under drought might also be associated with the increase in activities of photosynthetic enzymes.

Silicon nutrition seemed to be effective for improving cob length, cob diameter, number of grains per cob, biological and grain yield under water stress conditions (Tables 4-8). Drought stress condition significantly reduced the growth and development but $\mathrm{Si}$ supplement maintained the increase in yield and related attributes in maize. Ali et al. (2012) reported that silicon application of $150 \mathrm{mg} / \mathrm{kg}$ to salinity induced $(12 \mathrm{dS} / \mathrm{m})$ plants of wheat variety SARC-5 significantly improved several plant characteristics like plant height $(9.19 \%)$, spike length $(24.28 \%)$, number of grains per spike $(20.75 \%)$, 100-grain weight (10.24\%), biological yield (22.94\%) and grain yield (30.96\%), and harvest index (7.69\%). In fact, negative effects of drought stress on maize plants are minimized by $\mathrm{Si}$ nutrition through its positive role in maintaining water status of plants (Chen et al. 2011), photosynthetic efficiency (Zuccarini 2008), photosynthetic apparatus and pigments (Chutipaijit et al. 2012), ultra-structure of leaf organelles (Shu and Liu 2001), osmotic adjustment (Ahmad and Haddad 2011), plant defense system (Milne et al. 2012) and lowering transpiration (Zou et al. 2005).

In conclusion, silicon nutrition significantly improved the growth and yield of hybrid maize and was also useful in minimizing the negative effects of water deficit stress by improving the photosynthetic rate, lowering the transpiration rate and maintaining the leaf water status.

\section{Acknowledgement}

The work reported in this manuscript is a part of research work being conducted by $\mathrm{PhD}$ scholar Muhammad Amin whose study was funded by the Higher Education Commission through Indigenous Ph.D. Fellowship.

\section{References}

Abdalla, M.M. 2009. Sustainable effects of diatomites on the growth criteria and phytochemical contents of Vicia faba plants. 4th Conf. on Recent Technologies in Agriculture, November 2009. Faculty of Agriculture, Cairo University, Giza, Egypt. pp. 213-228.

Ahmad, S.T., Haddad, R. 2011. Study of silicon effects on antioxidant enzyme activities and osmotic adjustment of wheat under drought stress. Czech J. Genet. Plant Breed. 47:17-27.

Ahmed, M., Fayyaz-ul-Hassen, Qadeer, U., Aslam, M.A. 2011. Silicon application and drought tolerance mechanism of sorghum. Afr. J. Agric. Res. 6:594-607.

Ahmed, M., Kamran, A., Asif, M., Qadeer, U., Ahmed, Z.I., Goyal, A. 2013. Silicon priming: a potential source to impart abiotic stress tolerance in wheat: A review. Aus. J. Crop Sci. 7:484-491. 
Ali, A., Basra, S.M.A., Ahmad, R., Wahid, A. 2009. Optimizing silicon application to improve salinity tolerance in wheat. Soil and Environ. 28:136-144.

Ali, A., Basra, S.M.A., Iqbal, J., Hussain, S., Subhani, M.N., Sarwar, M., Ahmed, M. 2012. Augmenting the salt tolerance in wheat (Triticum aestivum) through exogenously applied silicon. Afr. J. Biotechnol. 11:642649.

Aranda, M.R., Jurado, O., Cuartero, J. 2006. Silicon alleviates the deleterious salt effect on tomato plant growth by improving plant water status. J. Plant Physiol. 163:847-855.

Ashraf, M., Foolad, M.R. 2007. Roles of glycine betaine and proline in improving plant abiotic stress resistance. Env. Exp. Bot. 59:206-216.

Beddington, J. 2010. Food security: contributions from science to a new and greener revolution. Philosophical Transactions of the Royal Society Biological Sci. 365:61-71.

Bokhtiar, S.M., Huang, H.R., Li, Y.R., Dalvi, V.A. 2012. Effects of silicon on yield contributing parameters and its accumulation in abaxial epidermis of sugarcane leaf blades using energy dispersive X-ray analysis. J. of Plant Nutr. 35:1255-1275.

Boubacar, I. 2012. The effects of drought on crop yields and yield variability: An economic assessment. Intl. J. Economics and Finance 4:51-60.

Chen, W., Yao, X., Cai, K., Chen, J. 2011. Silicon alleviates drought stress of rice plants by improving plant water status, photosynthesis and mineral nutrient absorption. Biol. Trace Elem. Res. 142:67-76.

Chutipaijit, S., Chaum, S., Sompornpailin, K. 2012. An evaluation of water deficit tolerance screening in pigmented indica rice genotypes. Pak. J. Bot. 44:65-72.

Farooq, M., Wahid, A., Kobayashi, N., Fujita, D., Basra, S.M.A. 2008. Plant drought stress, effects, mechanisms and management. Agron. Sustain. Dev. 29:185-212.

Food and Agriculture Organization of the United Nations (FAO) 2011. FAOSTATS. Rome, Italy. pp. 63-81. http://www.fao.org/docrep/013/i2050e/i2050e.pdf

Gao, X., Zou, C., Wang, L., Zhang, F. 2006. Silicon decreases transpiration rate and conductance from stomata of maize plants. J. Plant Nutr. 29:1637-1647.

Hakim, Y., Khan, A.L, Shinwari, Z.K., Kim, D., Waqas, M., Khan, M., Lee, I. 2012. Silicon treatment to rice (Oryza sativa L.) plants during different growth periods and its effects on growth and grain yield. Pak. J. Bot. 44:891-897.

Hamayun, M., Sohn, E.Y., Khan, S.A., Shinwari, Z.K., Khan, A.L., Lee, I.J. 2010. Silicon alleviates the adverse effects of salinity and drought stress on growth and endogenous plant growth hormones of soybean (Glycine $\max$ L.). Pak. J. Bot. 42:1713-1722.

Karrou, M., Oweis, T., El -Enein, R.A., Sherif, M. 2012. Yield and water productivity of maize and wheat under deficit and raised bed irrigation practices in Egypt. Afr. J. Agric. Res. 7:1755-1760.

Kojic, D., Pajevic, S., Galovic, A.J., Purac, J., Pamer, E., Skondric, S., Milovac, S., Popovic, Z., Lajsic, G. 2012. Efficacy of natural aluminosilicates in moderating drought effects on the morphological and physiological parameters of maize plants (Zea mays L.). J. of Soil Sci. and Plant Nutrition 12:113-123.

Kurdali, F., Al-Shammaa, M. 2010. Natural abundances of nitrogen and carbon indicative of growth and $\mathrm{N}_{2}$ fixation in potassium fed lentil grown under water stress. J. Plant Nutr. 33:157-174.

Kurdali, F., Al-Chammaa, M., Mouasess, A. 2013. Growth and nitrogen fixation in silicon and/or potassium fed chickpeas grown under drought and well watered conditions. J. of Stress Physiol. and Biochem. 9:385-406.

Majumdar, D.K. 2002. Irrigation Water Management: Principles and Practices. Prentice Hall of India. New Delhi, India. 487 p.

Mali, M., Aery, N.C. 2008. Influence of silicon on growth, relative water contents and uptake of silicon, calcium and potassium in wheat grown in nutrient solution. J. Plant Nut. 31:1867-1876.

Miao, B.H., Han, X.G., Zhang, W.H. 2010. The ameliorative effect of silicon on soybean seedlings grown in potassium-deficient medium. Ann. Bot. 105:967-973.

Milne, C.J., Laubscher, C.P., Ndakidemi, P.A., Marnewick, J.L., Rautenbach, F. 2012. Salinity induced changes in oxidative stress and antioxidant status as affected by applications of silicon in Lettuce (Lactuca sativa). Int. J. Agric. Biol. 14:763-768.

Nachabe, M. 1998. Refining the interpretation of field capacity in the literature. J. of Irrigation and Drainage Engineering 124:230-232. 
Nobel, P.S. 1983. Introduction to Biophysical Plant Physiology. W.H. Freeman and Co., Francisco, California, USA. pp. $484-486$.

Peleg, Z., Reguera, M., Tumimbang, E., Walia, H., Blumwald, E. 2011. Cytokinin-mediated source/sink modifications improve drought tolerance and increase grain yield in rice under water-stress. Plant Biotechol. J. 9:747-758.

Rafiq, M. 2001. A Textbook of Irrigation and Drainage Practices for Agriculture. University of Agriculture. Faisalabad, Pakistan, pp. 69-70.

Sacala, E. 2009. Role of silicon in plant resistance to water stress. J. Elementology 14:619-630.

Scholander, P.L., Hammel, H.T., Bradstreet, E.D., Hemminsoln, E.A. 1964. Hydrostatic pressure and osmotic potential in leaves of mangroves and some other plants. Proc. Natl. Sci. U.S.A. 52:119-125.

Savvas, D., Giotis, D., Chatzieustratiou, E., Bakea, M., Patakioutas, G. 2009. Silicon supply in soil less cultivations of zucchini alleviates stress induced by salinity and powdery mildew infections. Environ. and Exp. Bot. 65:11-17.

Shen, X., Zhou, Y., Duan, L., Li, Z., Eneji, A.E., Li, J. 2010. Silicon effects on photosynthesis and antioxidant parameters of soybean seedlings under drought and ultraviolet-B radiation. J. Plant Phys. 167:1248-1252.

Shu, L.Z., Liu, Y.H. 2001. Effect of silicon on growth of maize seedlings under salt stress. Agro-environ. Prot. 20:38-40.

Sonobe, K., Hattorri, T., An, P., Tsuji, W., Eneji, A.E., Kobayashi, S., Kawamura, Y., Tanaka, K., Inanaga, S. 2011. Effect of silicon application on sorghum root responses to water stress. J. Plant Nut. 34:71-82.

Steel, R.J.D., Torrie, J.H., Dickey, D.A. 1997. Principals and Procedures of Statistics. A Biometrical Approach. 3rd Ed. McGraw Hill Book Co. Inc. New York, USA.

Tariq, J.A., Usman, K. 2009. Regulated deficit irrigation scheduling on maize crop. Sarhad J. Agric. 25:441450.

Tuna, A.L., Kaya, C., Higgs, D., Amador, B.M., Aydemir, S., Girgin, A.R. 2008. Silicon improves salinity tolerance in wheat plants. Environ. and Exp. Bot. 62:10-16.

Turner, N.C. 1986. Crop water deficit: a decade of progress. Adv. Agron. 39:1-51.

Zou, C., Gao, X., Zhang, F. 2005. Silicon improves water use efficiency in maize plants (Zea mays L.). Third conference "Silicon in Agriculture". Uberlandia, Brazil. p. 123.

Zuccarini, P. 2008. Effects of silicon on photosynthesis, water relations and nutrient uptake of Phaseolus vulgaris under $\mathrm{NaCl}$ stress. Biologia Plantarum 52:157-160. 